\title{
Study of SMEs from electrical engineering industry providing smart services in the Czech Republic
}

\author{
Lucie Kaňovská ${ }^{1, *}$ and Veronika Bumberová ${ }^{1}$ \\ ${ }^{1}$ Brno University of Technology, Faculty of Business and Management, Kolejní 2906/4, 61200 Brno, \\ Czech Republic
}

\begin{abstract}
.
Research background: A buzzword such as industry 4.0, digitalization and smart services are tracking economic news in recent time. The world has changed over the last decade from a mainly physical to software controlled economy. Many manufacturers provide a lot of accompanying services to their products. However, not all of them supply smart services with the expectation of achieving better performance, portfolio expansion and long-term cooperation with their customers.

Purpose of the article: The aim of the paper is to find out differences between providers and non-providers of smart services and across subcategory of smart service providers in cooperation flexibility, innovation flexibility in product and accompanying services and performance.

Methods: A quantitative research was held among 112 electro-technical SMEs in Czech Republic. The analysis is based on descriptive statistics and non-parametric tests to compare the differences in electrical industry and across providers of smart services in key areas.

Findings \& Value added: The findings show that the differences are statistically significant. The results in the field of electrical engineering suggest that the found diversity (patterns of behavior) could also help managers in this field and policies aimed at supporting the development of small businesses in this context.
\end{abstract}

Keywords: smart technology services; electro-technical industry; manufacturers; SMEs; Czech Republic

JEL Classification: O14; L6; L25

${ }^{*}$ Corresponding author: kanovska@,fbm.vutbr.cz 


\section{Introduction}

The paper focuses on the area of accompanying services using smart technologies (hereinafter referred to as smart services), which manufacturing companies provide to their customers. Smart services are a special type of service that is provided to a smart object able to perceive its own conditions and its surroundings, thus enabling up-to-date data collection, constant communication and interactive feedback [1]. Smart services have "raised high expectations of their potential" [2] and are widely used to describe a company's innovation.

In contrast, the research area of these services is still in its infancy, and it is only in recent years that possible first strategies for their research have emerged (e.g. [3]). The field of smart services is a relatively new and little-studied research area, which offers only a limited number of relevant contributions and at the same time deals with only one area of digital technology instead of a comprehensive grasp of issues covering the full range of relevant digital technologies. Therefore, there is a need for more detailed research in order to systematize existing knowledge in this area [4]. The aim of the paper is to find out if there are some differences between providers and non-providers of smart services and some differences across subcategory of smart service providers (grouping by scope and typology of services offered) in cooperation flexibility, innovation flexibility in product and accompanying services and performance.

The structure of this paper is following: the first chapter describes the definition, importance of smart services and also the designation of electric equipment and components industry, the second chapter provides information regarding to methodology, the details of data collection and analytical methods, the third chapter presents the main findings of the analyses and discussion related to the proposed research questions. The last chapter summarizes the conclusions of the study and provides the implications for future research.

\subsection{Definition and importance of smart services}

According to [1], it will soon be insufficient for a company to offer services, it will have to provide smart services. But what exactly are smart services provided by manufacturers? Smart services have many different definitions and interpretations. According to [1], smart services and smart service systems can be defined as "the application of specialized capabilities through the actions, processes and performance enabled by smart products". According to [5] smart services are formed by introducing smart devices into the digital service system. Smart device networks coordinate the digital competencies of the parties that are part of the digital service system and / or mediate their interactions. Smart devices show physical and digital properties at the same time, so it is possible to observe, identify and analyze physical and digital events, make decisions and perform physical and / or digital actions. Therefore, it can be said that smart services are able to integrate physical and digital competencies in a complex socio-technical system of services. According to [6], services using smart technologies are defined as services tailored for specific customers using data and smart processes.

"Smart technology services are technology-mediated services actively provided by the supplier through remote access and data exchange via built-in controllers and / or feedback devices." stated [7]. [8] defines smart services as "digital services that are delivered through intelligent and networked IT infrastructure and value generation in a system combined with physical objects / products through continuous data collection and analysis." For services that use smart technologies, it uses the term "smart services" in English literature, but there are also other terms and possible definitions, especially in professional journals, so it is 
clear that many terms are used in the same or similar contexts and refer to similar concepts, making it difficult to distinguish them correctly. Concept of smart services has been used in various industries such as science and education, manufacturing, industry, healthcare or for individuals, such as smart homes, which presents huge opportunities and complexity but also diverse barriers, need understanding, definition and development [9].

However, since these services very often expand the company's product and are usually offered with it, this paper works with the term smart services and uses the concept of [7] "technology-mediated services actively provided by the supplier through remote access and data exchange via built-in control devices and / or feedback devices". Despite the accelerating development of smart services, scientific research is still in its infancy [3]. Of course, interest in this area of research is growing among the authors. Great attention is paid to the designation of these smart services that industrial companies can offer to their customers. The designation shows certain differences in the perception of these services due to their constant innovations. For example, some authors use other terms, such as: teleservices [10], tele-maintenance [11], telematics [12], e-service [13], e-maintenance [14], remote repair, diagnostics and maintenance (RRDM) [15].

Obviously, there is a large number of possible designations for smart services in the industry. The designation has evolved over time and has expanded its concept - from transmission, remote repair to diagnostics and prognosis. It is therefore clear that there is still great diversity among the designations of smart services in industry by the authors of scientific publications, but almost all used terms describe the same principle. The key principle of these smart services is a combination of technologies using software and hardware that allow the collection of remote data on the performance and use of products in order to determine their current and predictive status [16]. Even among managers of manufacturing companies, there is a certain ambiguity in the designation of smart services. Possible designations in manufacturing companies are, for example: Digital Service, Intelligent Service, Intelligent Solutions, Remote Monitoring Solution, Remote Monitoring Technologies, Remote Diagnostics, Smart Solutions, Telemetry System.

Possible benefits of smart services in manufacturing companies for customers, identified in quantitative research held by [7], include: better reliability (such as fault prevention), faster speed of service delivery (e.g. faster problem resolution), better costbenefit ratio (e.g. lower price for the same benefit), higher efficiency (e.g. process optimization), higher service quality (e.g. reduced failure rate), more flexible service delivery (e.g. easy service planning), better adaptation to user needs (e.g. flexible solution configuration), etc. Similarly, according to [1], customers perceive the benefits of smart services in preventing unpleasant surprises during production, which can take less downtime, optimize maintenance planning, increase safety, improve information flow and transparency, as well as reduce labor costs and creating a better working environment, etc.

The potential benefits for providers, mostly manufacturers, identified in quantitative research from [7], include: increase in margins, cost reduction, generating additional sales, realization of higher prices, use of new business opportunities, gathering valuable information, increase customer satisfaction, increase the ability to retain customers, expanding interactions with investors, strengthening the image, differentiation from the competition, risk reduction, etc. [9] identified 18 different benefits from providing services, which they further grouped into five groups: 1) benefits that generally describe the cost and time reduction effects of smart services, 2) benefits that generally improve facilities, or conditions through the smart services application, which was the most frequently mentioned benefit group, 3) benefits based on customer-related benefits, 4) benefits associated with monitoring and maintenance, which was the second most frequently mentioned benefit group, and 5) various, i.e. beneficial factors that do not apply to any of the other groups mentioned above (e.g. as: safety, environmental benefits, partnerships). 
Moreover, manufacturers should be able to present these benefits to their customers and to possible partners properly.

\subsubsection{Defining of electric equipment and components industry}

For the processing of empirical research, sections CZ-NACE 26 (Manufacture of computer, electronic and optical products) and CZ-NACE 27 (Manufacture of electrical equipment) were selected from the classification of economic activities issued by the European Commission. The division CZ-NACE 26 includes the manufacture of computers, computer peripherals, communications equipment, and similar electronic products, as well as the manufacture of components for such products. Production processes of this division are characterised by the design and use of integrated circuits and the application of highly specialised miniaturisation technologies. The division also contains the manufacture of consumer electronics, measuring, testing and navigating equipment, irradiation, electromedical and electrotherapeutic equipment, optical instruments and equipment, and the manufacture of magnetic and optical media. The division CZ-NACE 27 includes the manufacture of products that generate, distribute and use electrical power. Also this division includes the manufacture of electrical lighting, signaling equipment and electric household appliances.

Companies from section CZ-NACE 26, i.e. from electronics and electrical engineering, are subcontractors for many other sectors of the economy, such as the automotive industry and mechanical engineering. Part of the section is labor-intensive production and highly productive automated production. Section CZ-NACE 27 belongs to the historically important branches within the manufacturing industry. This section has a very strong position in the Czech economy and offers a wide range of products. The nature of the products of the electrical engineering industry is a prerequisite for the competitiveness of other branches of the manufacturing industry and energy. This division is one of the most important employers in the manufacturing industry [17].

Companies from both sections focus mainly on B2B markets and there is no such dependence on fashion trends as in companies that focus their production mainly on B2C markets. The importance of these companies is essential for the existence and competitiveness of other sectors. The Gartner study shows the advancing digitization of businesses. It is assumed that in the coming years, customers will demand savings from the operation of, for example, their computers and their slower obsolescence, new security options, as well as better services [17].

\section{Methodology}

Manufacturers progressively use servitization and digitalization, but academic research in this field is still relatively recent $[18,19]$. To focus more on this topic, the research was held. There are 278 companies in CZ-NACE 26 and 575 companies in CZ-NACE 27 with 10 - 250 employees according to Czech Statistical Office (CSO). Totally there are 853 companies (data are from December 2019). Small and medium manufacturers were selected from the Amadeus database. Mostly managers and directors were contacted by email and asked to fill out a questionnaire, which was web-based. Incomplete questionnaires were discarded. The data was collected from July to October 2019. The total number of SMEs from selected CZ-NACE in the Amadeus database was 730. For more detail see table 2. All 730 companies were contacted, but 22 emails were sent back immediately. These companies have already ceased to exist or are in liquidation or contact emails were missing and the companies were no longer traceable. In total, 112 fully completed questionnaires 
were received back. The questionnaire return rate corresponds to $15.8 \%$. The data analysis was done by the software package SPSS, Version 21.

Table 1. Structure of respondents according to CZ-NACE.

\begin{tabular}{|c|c|c|c|c|c|c|}
\hline \multirow{2}{*}{$\begin{array}{c}\text { CZ- } \\
\text { NACE }\end{array}$} & \multicolumn{2}{|c|}{$\begin{array}{c}\text { Theoretical } \\
\text { (CSO) }\end{array}$} & \multicolumn{2}{c|}{$\begin{array}{c}\text { Theoretical } \\
\text { (Amadeus) }\end{array}$} & \multicolumn{2}{c|}{$\begin{array}{c}\text { Empirical } \\
\text { (own research) }\end{array}$} \\
\cline { 2 - 7 } & Absolute & Relative & Absolute & Relative & Absolute & Relative \\
\hline 26 & 278 & 32.6 & 254 & 34.8 & 68 & 60.7 \\
\hline 27 & 575 & 67.4 & 476 & 65.2 & 44 & 39.3 \\
\hline Total & $\mathbf{8 5 3}$ & $\mathbf{1 0 0 \%}$ & $\mathbf{7 3 0}$ & $\mathbf{1 0 0} \%$ & $\mathbf{1 1 2}$ & $\mathbf{1 0 0} \%$ \\
\hline
\end{tabular}

We defined the null hypotheses for research purpose:

HO (1): There are no differences between providers and non-providers of smart services and across subcategory of smart service providers (grouping by scope and typology of services offered) in cooperation flexibility, innovation flexibility in product and accompanying services and performance.

Additional question is: "Is there dependence between provision of smart services with target markets or size of enterprises from electrical engineering industry?" The null hypothesis was defined from this question:

HO (2): The provision of smart services does not depend on characteristics such as size or orientation to the target markets.

The provision of smart services is measured by dichotomous variables coded " 1 ", if the manufacturers provide some type of smart services, otherwise " 0 ". Key areas are: external cooperation flexibility: with regard to customers and suppliers, internal cooperation flexibility, innovation flexibility for product, innovation flexibility for accompanying services, innovation performance and business performance. A Likert scale form from 1 to 5 was used for the questionnaire, where 1 means "No, I don't agree" and 5 means "Yes, I agree". The examination of out-put variables in key areas is based on index factor as the average score of multi-item scales (see the results of Cronbach's alpha for each index in table 3). The levels of reliability were good for all parts of the questionnaire except innovation performance and business performance, where the level of reliability is questionable.

Because the data exhibits skewness, which implies departures from normality, the distribution-free non-parametric tests are used to examine whether there some significant differences exist. The Mann-Whitney test is used for two group comparisons to test whether there are significant differences between providers and non-providers of smart services. Correspondingly, the Kruskal-Wallis test is used for multi-group comparisons to test whether there are significant differences within group of smart service providers according to scope and typology.

\section{Results and discussion}

Table 2 shows how many respondents provide smart services to their customers. According to the results, almost half of the respondents provide smart services. For medium-sized enterprises, $42.0 \%$ provide smart services and for small enterprises it is $48.4 \%$. More smart services are provided by manufacturers whose customers are from B2B market (48.0 $\%)$ than companies whose customers are from B2C market $(28.6 \%)$. Furthermore, the relationship between the provision of smart services and the characteristics of the 
companies in terms of size and target markets they serve was identified. Based on a p-value that is higher than the chosen significance level of 0.05 , the null independence hypothesis is not rejected. The size of the company and the target market do not have a significant effect on the smart service provision.

Table 2. Descriptive statistic and dependence testing by Pearson's chi-square test.

\begin{tabular}{|c|c|c|c|c|c|c|}
\hline $\begin{array}{c}\text { Characteristics } \\
\text { (categorical) }\end{array}$ & $\mathbf{N}$ & $\begin{array}{c}\text { Providers of } \\
\text { smart } \\
\text { services }\end{array}$ & $\begin{array}{c}\text { Non- } \\
\text { providers of } \\
\text { smart } \\
\text { services } \\
\end{array}$ & Value & df & $\begin{array}{c}\text { p- } \\
\text { value }\end{array}$ \\
\hline Small $(<50)$ & 62 & $30(48.4)$ & $32(51.6)$ & & & \\
\hline Medium $(>250)$ & 50 & $21(42.0)$ & $29(58.0)$ & & & \\
\hline Size & 112 & $51(45.5)$ & $61(54.5)$ & $.455^{\mathrm{a}}$ & 1 & .500 \\
\hline $\mathrm{B} 2 \mathrm{C}$ & 14 & $47(48.0)$ & $51(52.0)$ & & & \\
\hline $\mathrm{B} 2 \mathrm{~B}$ & 98 & $4(28.6)$ & $10(71.4)$ & & & \\
\hline Target markets & 112 & $51(45.5)$ & $61(54.5)$ & $1.857^{\mathrm{a}}$ & 1 & .173 \\
\hline
\end{tabular}

The following table 3 shows the highest and the lowest values of average values from the results of descriptive statistics and the full overview, including standard deviations. The items with the highest average value include "We strive to apply an individual approach to customers" (4.527) and "Our main customers want to continue working with us" (4.518). Both of these items concern flexibility in the field of external cooperation. On the contrary, the lowest average rating was given to the item related to innovation performance "Every year we come to the market with a high number of new products "(2.875) and then the item from flexibility in innovation for smart services provided, namely "We have enough capacity to create different variants".

Table 3. Descriptive statistics of identified factors.

\begin{tabular}{|l|c|c|c|c|c|c|}
\hline $\begin{array}{l}\text { Factors in key areas } \\
\text { (continuous/metric variables) }\end{array}$ & $\mathbf{N}$ & Min & Max & Std & Mean & Median \\
\hline $\begin{array}{l}\text { External cooperation flexibility with } \\
\text { customers } \\
\text { (Cronbach's alpha 0.792) }\end{array}$ & 112 & 1.20 & 5.00 & 0.66481 & 4.2768 & 4.4 \\
\hline $\begin{array}{l}\text { External cooperation flexibility with } \\
\text { suppliers } \\
\text { (Cronbach's alpha 0.812) }\end{array}$ & 112 & 1.60 & 5.00 & 0.77886 & 3.7246 & 3.8 \\
\hline $\begin{array}{l}\text { Internal cooperation flexibility } \\
\text { (Cronbach's alpha 0.814) }\end{array}$ & 112 & 1.20 & 5.00 & 0.78968 & 3.8768 & 4.0 \\
\hline $\begin{array}{l}\text { Innovation flexibility for product } \\
\text { (Cronbach's alpha 0.832) }\end{array}$ & 112 & 1.20 & 5.00 & 0.86925 & 3.4576 & 3.6 \\
\hline $\begin{array}{l}\text { Innovation flexibility for } \\
\text { accompanying services } \\
\text { (Cronbach's alpha 0.890) }\end{array}$ & 112 & 1.00 & 5.00 & 0.87725 & 3.3125 & 3.6 \\
\hline $\begin{array}{l}\text { Innovation performance } \\
\text { (Cronbach's alpha 0.677) }\end{array}$ & 112 & 1.20 & 5.00 & 0.71016 & 3.2518 & 3.2 \\
\hline $\begin{array}{l}\text { Business performance } \\
\text { (Cronbach's alpha 0.673) }\end{array}$ & 112 & 1.20 & 4.80 & 0.63997 & 3.5103 & 3.6 \\
\hline
\end{tabular}


The visualisation of mean score by each factor according to smart service provision is shown in the following Figure 1. The differences are already apparent.

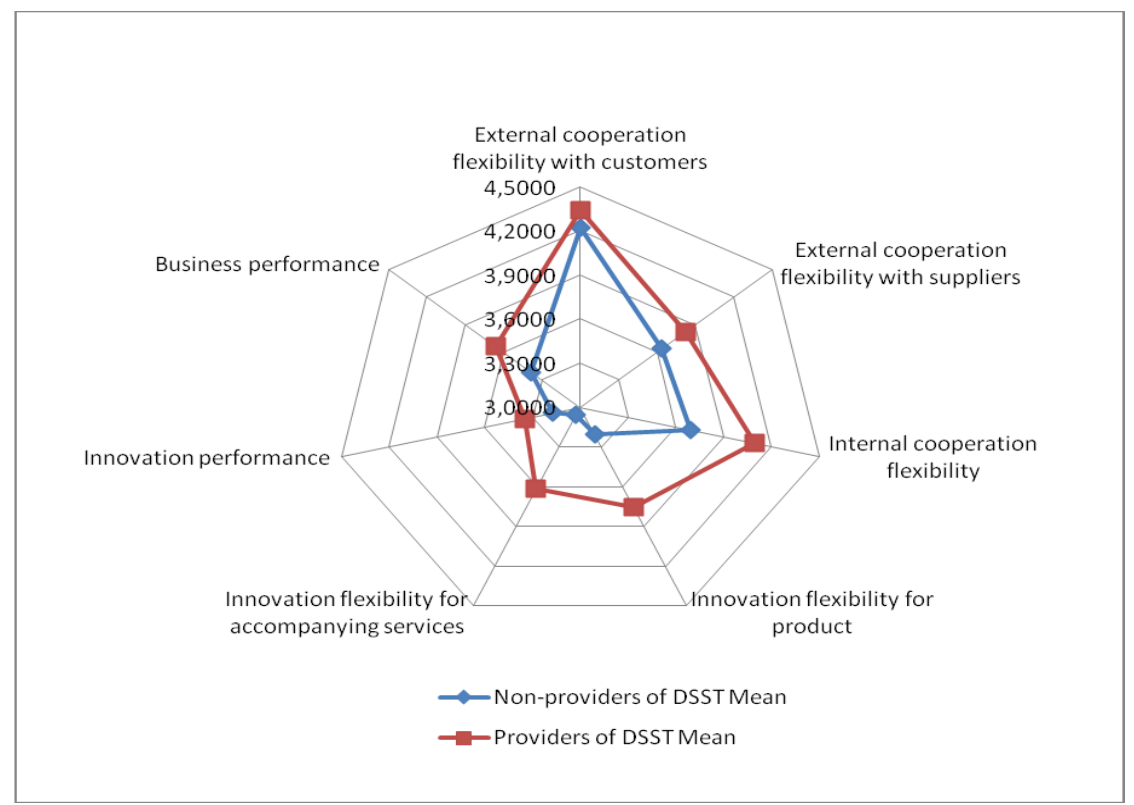

Fig. 1. Mean score factors of providers and non-providers of smart services.

Table 4 shows that significant differences in the average ranking of the surveyed areas between manufacturers providing and not providing smart services are in the area of internal cooperation flexibility, innovation flexibility for product, innovation flexibility for accompanying services and business performance. On the contrary, no statistically significant differences were found in the area of innovation performance and external collaboration flexibility with suppliers.

Table 4. Statistics of Mann-Whitney non-parametric tests for grouping variable.

\begin{tabular}{|c|c|c|c|c|}
\hline \multirow{2}{*}{ Description of SUM Factors } & \multicolumn{4}{|c|}{ Grouping variable: } \\
\cline { 2 - 5 } & $\begin{array}{c}\text { Mann- } \\
\text { Whitney U }\end{array}$ & Wilcoxon $\mathrm{W}$ & $\mathrm{Z}$ & Sig. $^{\mathrm{a}}$ \\
\hline $\begin{array}{c}\text { Innovation flexibility for } \\
\text { product }\end{array}$ & 973.500 & 2864.500 & -3.415 & $.001^{*}$ \\
\hline $\begin{array}{c}\text { Innovation flexibility for } \\
\text { accompanying services }\end{array}$ & 957.000 & 2848.000 & -3.519 & $.000^{* *}$ \\
\hline Innovation performance & 1374.500 & 3265.500 & -1.064 & .287 \\
\hline $\begin{array}{c}\text { Business performance } \\
\text { with customers }\end{array}$ & 1080.500 & 2971.500 & -2.797 & $.005^{*}$ \\
\hline $\begin{array}{c}\text { External cooperation flexibility } \\
\text { External cooperation flexibility }\end{array}$ & 1272.500 & 3163.500 & -1.670 & .095 \\
\hline Internal cooperation flexibility & 999.500 & 2890.500 & -3.266 & $.001^{*}$ \\
\hline
\end{tabular}

${ }^{\text {a }}$ Asymp. Sig. (2-tailed), * Sig. $\leq 0.05,{ }^{* *}$ Sig. $\leq 0.01$. 
The offering of smart services across providers is shown in the following Figure 2 . The most provided smart services are remote monitoring $(80.4 \%)$ and remote repair $(49.0 \%)$. No respondent added another type of smart service.

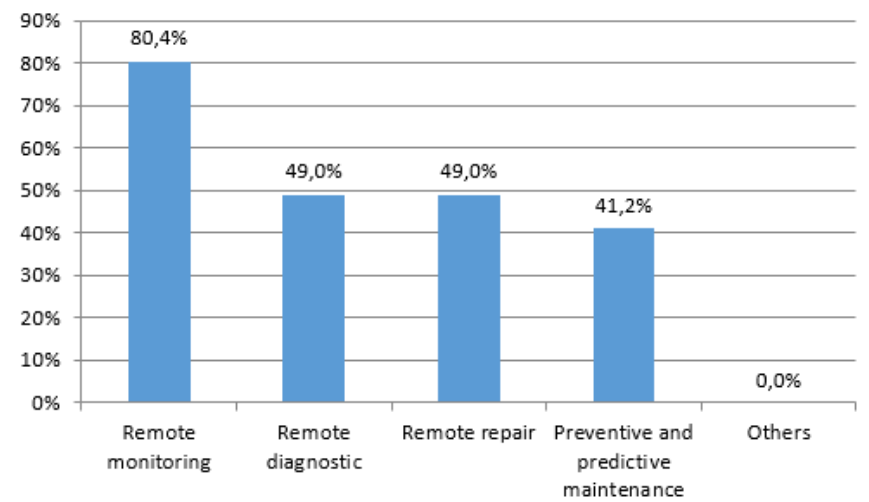

nelative frequencies

Fig. 2. Relative frequency of smart service offerings across providers.

However, the providers of smart services participating in the research could choose one or more types of services that they offer, so the total number is not equal to the total number of respondents. It can be said that three groups of manufacturers were found, which differ according to their smart service offering: 1) the offering includes a separate single smart service $(17.6 \%), 2)$ the offering includes a mix (2-3) of several types of smart services $(54.9 \%)$ and 3$)$ the offering includes a comprehensive portfolio of smart services in a given area $(21.6 \%)$. Table 5 shows statistic of non-parametric Kruskal-Wallis test to test the differences between each group across providers of smart services.

Table 5. Statistics of Kruskal-Wallis non-parametric test for grouping variable.

\begin{tabular}{|c|c|c|c|}
\hline \multirow{2}{*}{ Description of SUM Factors } & \multicolumn{3}{|c|}{$\begin{array}{c}\text { Grouping variable: } \\
\text { cluster membership (3) }\end{array}$} \\
\cline { 2 - 4 } & Chi-Square & $\mathrm{df}$ & Sig. \\
\hline $\begin{array}{c}\text { Innovation flexibility for } \\
\text { product }\end{array}$ & 2.121 & 2 & .346 \\
\hline $\begin{array}{c}\text { Innovation flexibility for } \\
\text { accompanying services }\end{array}$ & 1.335 & 2 & .513 \\
\hline $\begin{array}{c}\text { Innovation performance } \\
\text { Business performance }\end{array}$ & .506 & 2 & .777 \\
\hline $\begin{array}{c}\text { External cooperation flexibility } \\
\text { with customers }\end{array}$ & 2.716 & 2 & .257 \\
\hline $\begin{array}{c}\text { External cooperation flexibility } \\
\text { with suppliers }\end{array}$ & 4.409 & 2 & .110 \\
\hline Internal cooperation flexibility & 3.581 & 2 & .167 \\
\hline
\end{tabular}


The hypothesis is not rejected $(<0.05)$ and we can state that there are no significant differences between smart service providers in any key area with regard to scope or typology of offered services.

\section{Conclusion}

Almost half of electrical engineering companies participating in the research provide smart services to their customers in the Czech Republic. Differences in the provision of smart services do not depend on characteristics according to the number of employees or target markets. Remote monitoring, diagnostics and repairs are most often provided in population of electric engineering industry. A statistically significant difference between companies providing and not providing smart services was demonstrated in the area of internal cooperation flexibility, innovation flexibility for products as well as innovation flexibility for provided accompanying services and business performance. It can be said that when companies provide smart services, then they concentrate more efforts in these areas, which is reflected in the improvement of the overall business performance. However, top managers must realize how to force their essential abilities and practises to form new mindset for the transformational shifts demanded in a digital servitization [20].

We didn't find statistically significant differences between providers of smart services in terms of scope or typology. What do these results suggest regarding the SMART services in of electrical engineering industry? Managers in these firms (and policies aimed to supporting this industry) who lay too much emphasis on the innovation performance may be led to ignore or misperceive that smart services as addition to products offered do not increase innovation performance, but they build a value for customers. This could help to improve overall customer satisfaction and thus the company's performance (increased sales, etc.).

\section{References}

1. Allmendinger, G., Lombreglia, R. (2005). Four strategies for the age of smart services. Harvard business review, 83(10), 131.

2. Klein, M. M. (2017). Design rules for smart services (Doctoral dissertation, PhD Thesis. University of St. Gallen).

3. Wünderlich, N. V., Heinonen, K., Ostrom, A. L., Patricio, L., Sousa, R., Voss, C., Lemmink, J. G. (2015). "Futurizing" smart service: implications for service researchers and managers. Journal of Services Marketing, 29(6-7), 442-447.

4. Grubic, T., Jennions, I. (2018). Remote monitoring technology and servitised strategies - factors characterising the organisational application. International Journal of Production Research, 56(6), 2133-2149.

5. Beverungen, D., Matzner, M., Janiesch, C. (2017). Information systems for smart services.

6. Hermann, M., Pentek, T., Otto, B. (2016). Design principles for industrie 4.0 scenarios. In T. X. Bui \& R. H. Sprague (Eds.) Proceedings of 2016 49th Hawaii international conference on system sciences (HICSS) (pp. 3928-3937). Dortmund: IEEE Computer Soc.

7. Töytäri, P., Turunen, T., Klein, M., Eloranta, V., Biehl, S., Rajala, R. (2018). Aligning the mindset and capabilities within a business network for successful adoption of smart services. Journal of Product Innovation Management, 35(5), 763-779. 
8. Paluch, S. (2017). Smart Services - Analyse von strategischen und operativen Auswirkungen. In Dienstleistungen 4.0 (pp. 161-182). Wiesbaden: Springer Gabler.

9. Hansen, H. R., Mendling, J., Neumann, G. (2019). Wirtschaftsinformatik. De Gruyter Oldenbourg.

10. Borgmeier, A. (2002). Einleitende Überlegungen. In Teleservice im Maschinen-und Anlagenbau (pp. 1-12). Wiesbaden: Deutscher Universitätsverlag.

11. Garcia, E., Guyennet, H., Lapayre, J. C., Zerhouni, N. (2004). A new industrial cooperative tele-maintenance platform. Computers \& Industrial Engineering, 46(4), 851-864.

12. Chatterjee, A., Greenberg, J., Jones, M., Kaas, H. W., Wojcik, P. (2001). Telematics: decision time for detroit. Business Strategy Review, 12(2), 21-38.

13. Rowley, J. (2006). An analysis of the e- service literature: towards a research agenda. Internet research, 16(3), 339-359.

14. Levrat, E., Iung, B., Crespo Marquez, A. (2008). E-maintenance: review and conceptual framework. Production Planning \& Control, 19(4), 408-429.

15. Biehl, M., Prater, E., McIntyre, J. R. (2004). Remote repair, diagnostics, and maintenance. Communications of the ACM, 47(11), 100-106.

16. Grubic, T., Peppard, J. (2016). Servitized manufacturing firms competing through remote monitoring technology. Journal of Manufacturing Technology Management. 27(2), 154-184.

17. Ministerstvo průmyslu a obchodu. (2018, October 30). Zpráva o vývoji malého a středního podnikání a jeho podpoře $v$ roce 2017. MPO. Retrieved from: https://www.mpo.cz/cz/podnikani/male-a-stredni-podnikani/studie-a-strategickedokumenty/zprava-o-vyvoji-maleho-a-stredniho-podnikani-a-jeho-podpore-v-roce2017--241070/

18. Beverungen, D., Breidbach, C. F., Poeppelbuss, J., Tuunainen, V. K. (2019). Smart service systems: An interdisciplinary perspective. Information Systems Journal, 29(6), 1201-1206.

19. Raddats, C., Kowalkowski, C., Benedettini, O., Burton, J., Gebauer, H. (2019). Servitization: A contemporary thematic review of four major research streams. Industrial Marketing Management, 83, 207-223.

20. Tronvoll, B., Sklyar, A., Sörhammar, D., Kowalkowski, C. (2020). Transformational shifts through digital servitization. Industrial Marketing Management, 89, 293-305. 